\title{
WIZJA BEZPIECZEŃSTWA W BASENIE MORZA ŚRÓDZIEMNEGO W ŚWIETLE WYSTĄPIEŃ PAŃSTW REGIONU W DEBACIE GENERALNEJ 67. SESJI ZGROMADZENIA OGÓLNEGO NARODÓW ZJEDNOCZONYCH (NOWY JORK, 25 WRZEŚNIA-1 PAŹDZIERNIKA 2012 R.)
}

\author{
amb. Wojciech A. Jasiński \\ Instytut Afrykański, ul. Kilińskiego 177, lok. 12, 90-950 Łódź
}

\begin{abstract}
Streszczenie. Debaty generalne dorocznych sesji Zgromadzenia Ogólnego (ZO), w których udział biorą wysokiej rangi przedstawiciele państw członkowskich Narodów Zjednoczonych (NZ) przyciągają uwagę opinii publicznej. Dla regionu BMŚ debata podczas 67. sesji miała szczególne znaczenie ze względu m.in. na fakt, że wzięło w niej udział po raz pierwszy wielu nowych przywódców państw po wydarzeniach arabskiej wiosny z 2011 r. Odbiły się one szerokim echem w kluczowych wystąpieniach przywódców państw, antycypując wydarzenia, z jakimi przyszło nam się mierzyć w ostatnich latach. Debaty generalne dorocznych sesji ZO stanowią więc cenne i systematyczne źródło informacji, ale także inspirację do działań na uniwersalnym forum, jakim są agendy systemu NZ.
\end{abstract}

Słowa kluczowe: 67. sesja ZO ONZ, region Morza Śródziemnego, arabska wiosna

1. Debaty generalne dorocznych sesji Zgromadzenia Ogólnego (ZO), w których udział biorą wysokiej rangi przedstawiciele państw członkowskich Narodów Zjednoczonych (NZ) ze zrozumiałych względów przyciągają uwagę opinii publicznej. Dla regionu BMŚ debata podczas 67. sesji miała szczególne znaczenie ze względu m.in. na fakt, że wzięło w niej udział po raz pierwszy wielu nowych przywódców państw po wydarzeniach arabskiej wiosny z 2011 r., i z powodu jej następstw, które przetoczyły się przez południową flankę BMŚ, rozchodząc się $\mathrm{z}$ różnym natężeniem po całym niemal świecie. Innym aspektem zwiększonego zainteresowania jest to, że w 2012 r. przewodnictwo sesji przypadło przedstawicielowi grupy Europy Wschodniej, w tym przypadku Serbii. Przewodniczący Vuk Jeremić nadmienił, że sam wywodzi się z państwa założyciela NZ - b. Jugosławii, a więc państwa leżącego wówczas w granicach BMŚ; państwa, z którego 
rozpadu wyłoniło się kilka mniejszych państw przylegających bezpośrednio do Morza Śródziemnego. Fakt, że sesja przypadała na okres: wyborów w Stanach Zjednoczonych, oczekiwanych zmian we władzach Chin oraz kryzysu w Unii Europejskiej, w tym na tle nowej perspektywy budżetowej na lata 2014-2020, a jednocześnie uhonorowania Pokojową Nagrodą Nobla (2012), prace 67. Sesji ZO koncentrowały szczególną uwagę na tych właśnie problemach.

Patrząc z perspektywy członkostwa NZ, trzeba zauważyć, że w nomenklaturze ONZ państwa BMŚ zaliczane są do czterech z pięciu grup geograficznych: 5 do Afryki (Maroko, Algieria, Tunezja, Libia, Egipt); 3 do Azji (Liban, Syria, Cypr); 5 do Europy Wschodniej (Słowenia, Chorwacja, Czarnogóra, Bośnia i Hercegowina, Albania); i 7 pozostałych do Europy Zachodniej i innych (Hiszpania, Francja, Włochy, Grecja, Malta, Turcja i Izrael). Łącznie 20 państw członkowskich i Autonomia Palestyńska, posiadająca status państwa nieczłonkowskiego. Grupy geograficzne wykorzystywane są obecnie głównie do celów wyborczych i obsadzania rotujących stanowisk w prezydiach (biurach) organów, komisji i komitetów NZ. ${ }^{1}$ Już jednak nawet ten formalny podział wskazuje na złożoność sytuacji w BMŚ. O ile kwestie wyborcze nie wywołują na ogół w tych grupach większych kontrowersji, o tyle w sprawach merytorycznych, jak wykazuje praktyka, doprowadzenie do konsensusu w ONZ jako całości nie jest zadaniem łatwym.

2. Inaugurując debatę, V. Jeremić stwierdził m.in., że podobnie jak wiele innych krajów, Serbia przechodziła wzloty i upadki. Pod koniec XX wieku Jugosławia, członek założyciel NZ, pogrążyła się w wojnie domowej, która pozostawiła głębokie rany. Teraz ta bolesna era się zakończyła. Serbia znów stanęła z wiarą przed społecznością międzynarodową, by we wspólnym interesie kształtować świat, w którym triumfować będą pokój i prawo międzynarodowe. ${ }^{2}$ Zgromadzenie Ogólne jest „,wielkim panteonem nadziei” dla ludów świata w dążeniu do ustanowienia dobrze działającego systemu międzynarodowego prowadzącego do sprawiedliwości i gwarantującego równe prawa i godność wszystkim państwom. Obecny krajobraz polityczny różni się od poprzednich tym, że jest pełen globalnych współzależności. Państwa aspirują do odgrywania większej roli w swych regionach i poza nimi. Powoduje to, że trudniej jest o kompromis.

To, co kiedyś zależało wyłącznie od państw, tak jak wojny, zadawanie cierpień na wielką skalę, znalazło się w zasięgu możliwości aktorów niepaństwowych. Stąd potrzeba znalezienia drogi do działania w zespole, tak by uprawnione potrzeby i troski wszystkich państw były zaspokojone, a jednocześnie by możliwa była realizacja ludzkich aspiracji. Dodatkowo, istnieje potrzeba poszukiwań dróg upodmiotowienia człowieka (empowerment), tzn. zadośćuczynienia krzywdom,

1 J. Rydzkowski Organizacja Narodów Zjednoczonych - przewodnik polityczny, Warszawa 2012, s. 181.

$2<$ http://gadebate.un.org/67/president-67th-session-unga-opening > Podobny początek przypisu z powołaniem się na państwo, dotyczy odpowiednio innych wystąpień w tej debacie, przywoływanych przez autora tekstu. 
wsłuchiwania się w opinie ludzi co do kształtowania ich przyszłego losu, scenariusza najbardziej rzucającego się w oczy na Bliskim Wschodzie. Są jednak obawy, że arabska wiosna, w sposób niezamierzony, wywołała także niepożądane skutki, a wśród nich, napięcia etniczne i plemienne, które wydawało się, że już uległy zatarciu. Wynik szlachetnego poszukiwania upodmiotowienia człowieka zależeć będzie od tego, jak te i podobne im zagrożenia zostaną potraktowane. Biorąc pod uwagę globalne polityczne i gospodarcze znacznie regionu, należy stwierdzić, iż konsekwencje wydarzeń będą miały dalekosiężne implikacje dla świata. Stąd bardziej niż kiedykolwiek przedtem widoczna jest potrzeba, by świat się do siebie zbliżył i by w sposób uniwersalny i pełny przestrzegano ustalonych zasad. Selektywne wymuszanie owych zasad szybko pozbawi ich zaufania jako podstawy istnienia. Taki scenariusz nie leży w interesie NZ. Ważne jest to, by wysiłki zmierzały w kierunku umocnienia szacunku dla zasad suwerenności i terytorialnej integralności państwa.

Karta NZ wymaga, by strony sporu najpierw szukały rozwiązań w drodze m.in. negocjacji, mediacji, arbitrażu czy uregulowania sądowego. Mając to na uwadze, zaproponowano temat debaty z 2012 r., dotyczącej pokojowego rozstrzygania sporów. Pokój to nie sytuacja braku wojny; on wymaga pojednania tych, którzy znaleźli się w sporze. Tylko w ten sposób może być zapewniony trwały pokój. „Rozwiązanie międzynarodowego problemu może być osiągnięte tylko w drodze odrzucenia jednostronnego podejścia (unilateral approach) i tylko jeśli strony zobowiążą się do jego rozwiązania". W takiej sytuacji Zgromadzenie może podjąć się roli „moralnego gwaranta” czegoś, co zostało już uzgodnione. Cenne zatem byłyby propozycje odnośnie do tego, jak można by jeszcze ulepszyć istniejące już mechanizmy pokojowego rozstrzygania sporów i rewitalizację roli Zgromadzenia.

Jeśli idzie o inne pierwszoplanowe sprawy debaty, to ważna będzie kwestia agendy rozwojowej po roku 2015 i zapewnienia źródeł jej finansowania. Większy akcent powinien być też położony na wzrost gospodarczy, tworzenie miejsc pracy, zielona produkcję towarów, ale i takież usługi w bardziej sprawiedliwych warunkach handlu. Postęp powinien też następować w kwestii globalnego zarządzania gospodarczego na linii Zgromadzenie-instytucje finansowe-G-20. Niedostatecznie wykorzystywany jest też mechanizm Alliance of Civilizations.

Narody Zjednoczone będą w takim stopniu silne, w jakim będą tego chciały państwa członkowskie. „Instytucja jest wydłużonym cieniem człowieka” (cytat za Ralph Waldo Emersonem). Od pradawnych czasów próbowano rozwiązywać spory drogą pokojową. Kulminacją tych wysiłków jest ,najpewniejszy przewodnik" - Karta NZ. Nie brakuje wyzwań, problem polega na tym, by podchodzić do realizacji sprostania im ze wspólną wiarą i wspólnie wytyczonym celem.

3. Sekretarz Generalny NZ, Ban Ki-moon, w swoim wystąpieniu podkreślił m.in., że „w tym roku jesteśmy tu, by bić na alarm z powodu kierunku w jakim zdąża ludzka rodzina. Widzimy proces narastającego niebezpieczeństwa i niesprawiedliwości, nierówności i nietolerancji. Rządy tracą cenne fundusze 
na śmiercionośne zbrojenia, zmniejszając inwestowanie w dobro ludzi”. Do tego dochodzą zgubne skutki zmian klimatu dokonujące się „na naszych oczach”, a mimo to wielu ludzi będących przy władzy tego zagrożenia nie zauważa. „To są czasy wielkiego zamieszania (turmoil), procesu zmian (transition) i transformacji ustrojowych; okresu, w którym czas nie jest po naszej stronie, i kiedy ludzie domagają się pracy i perspektyw na przyzwoite życie. Niestety, to czego doświadczają, to dzielenie ich, opóźnienia działań, odmawianie im szans na spełnienie marzeń i aspiracji”.

Zmiany w składach delegacji na bieżącą sesję ZO świadczą o nowym przypływie pragnienia postępu - nieprzypadkowo bowiem wielu przywódców państw przybyło tu po raz pierwszy. Ci nowi liderzy to wynik wiary zbuntowanych mas w to, że skończą oni z niechlubną przeszłością, i to od zaraz, a nie w bardziej odległej przyszłości. Chcą wizji, przywództwa i konkretnych nadziei na przyszłość. Naszym zadaniem jest odpowiedzieć na te frustracje i pragnienia. By temu sprostać, naszym zdaniem, niezbędne jest zastosowanie pięciu imperatywów: „trwałego rozwoju, prewencji, budowy bezpiecznego świata, pomocy krajom w okresie przejściowym oraz upodmiotowienia (empowerment) kobiet i młodzieży".

Wiele kroków w tym kierunku zostało podjętych; w krajach arabskich w ramach demokratycznej transformacji, w Myanmar (d. Birmie), i gdzie indziej. „Potrzebujemy jednak dać więcej od każdego z nas samych, a światu więcej od NZ. Trwały i sprawiedliwy rozwój jest kluczem do spełnienia nadziei ludzkości".

4. Minister SZ Algierii, Mourad Medelci, oświadczył, że świat znalazł się w punkcie zwrotnym z powodu geopolitycznych wydarzeń na Bliskim Wschodzie (BW) i globalnego kryzysu gospodarczego. „Wspólna wiara w skuteczność multilateralizmu powinna pozwolić na sprostanie tym wyzwaniom" i zapobiec rozlaniu się kryzysu w krajach uprzemysłowionych na inne regiony, zwłaszcza na Afrykę. Powrót zaufania i wzrostu gospodarczego powinien pomóc w lepszej koordynacji pracy instytucji finansowych z Bretton Woods. Algieria podejmuje energiczne działania oszczędnościowe i na rzecz sprawiedliwszego dzielenia tworzonego dobra. $\mathrm{Z}$ zadowoleniem powitał zmiany dokonujące się w Afryce Północnej i na BW, powodowane walką o ideały demokracji, sprawiedliwości i wolności. Jednocześnie potępił wszelkie formy przemocy i represji. Wyraził nadzieję na zażegnanie konfliktu w sprawie Sahary Zachodniej między Marokiem i Frontem Polisario. Podobnie wypowiedział się w kwestii syryjskiej - Algieria jest członkiem Special Joint Committee ONZ i Ligii Państw Arabskich z zadaniem monitorowania kryzysu w tym państwie. Z Algierii wywodzi się też nowy mediator, Specjalny Przedstawiciel SG NZ, Lakhdar Brahimi (poprzedni, Kofi Annan, zrezygnował z pełnienia tej misji). Mówca wskazał na powiązania przemocy i aktów terrorystycznych ze zorganizowaną przestępczością i nielegalnym handlem ludźmi. Skomplikowana sytuacja w Mali poważnie grozi całemu regionowi Sahelu. Algieria współdziała z Ekonomiczną Wspólnotą Państw Afryki Zach. (ECOWAS), Unią Afrykańską (UA) i innymi aktorami w osiągnięciu pokojowego i trwałego rozwiązania problemu. Trzeba zwalczać przejawy islamofobii, która 
sprzyja terroryzmowi. Zaproponował, by ONZ rozpatrzyła środki zapobiegające zbrodniom nienawiści (hate crimes). Odpowiedzialne i adekwatne stosowanie wolności słowa jest niezbędne do prowadzenia partnerskiego dialogu między narodami i różnymi religiami. Poparł prawo Palestyny w granicach z 1967 r. do członkostwa ONZ, jak również stworzenie strefy wolnej od broni nuklearnej na BW, a także inicjatywę Finlandii zwołania konferencji ws. BW. Poparł działania na rzecz trwałego rozwoju, przy czym podkreślił, iż związane z tym koszty powinny być ponoszone w myśl zasady wspólnej, ale zróżnicowanej odpowiedzialności w kwestiach budowania zdolności administracyjnej, transferu technologii i finansowania. Algieria jest jednym z krajów reprezentowanych w komisji ds. celów rozwoju po roku 2015 (Post-2015 development agenda).

Książę następca tronu Maroka, Moulay Rachid, podkreślił, że zmiany w regionie są odbiciem woli wielu ludów budowania demokratycznego społeczeństwa, w którym respektowane będą prawa człowieka i równe możliwości dla godnego życia. Tunezja, Libia, Egipt i Jemen zapoczątkowały nową erę postępu na drodze do demokracji, mimo skomplikowanego i niespokojnego otoczenia politycznego. Jako członek Rady Bezpieczeństwa Maroko znacząco przyczyniło się do mobilizacji międzynarodowego wsparcia dla inicjatyw i rezolucji Ligii Państw Arabskich w celu wymuszenia na władzach syryjskich przerwania aktów przemocy. Popiera prawo Palestyńczyków do odzyskania praw narodowych do utworzenia niepodległego państwa żyjącego w pokoju i bezpieczeństwie z Izraelem i wzywa do wznowienia rozmów w tej sprawie. Nie będzie pokoju bez stolicy państwa palestyńskiego we Wschodniej Jerozolimie. Spór o Moroccan Sahara książę nazwał „sztucznym sporem regionalnym”, którego realistyczne i wzajemnie akceptowalne rozwiązanie powinno zagwarantować Maroku „narodową jedność królestwa i integralność terytorialną, re-unifikację i poszanowanie charakterystyk (tożsamości) ludności regionu”. Stwierdził, iż Maroko będzie współdziałać z Misją NZ ds. Referendum w Zachodniej Saharze (MINURSU).

Prezydent Tunezji, Muncef Marzouki, podkreślił, że wolność i demokracja, którymi cieszy się obecnie społeczeństwo, zostały okupione wysoką ceną w postaci dziesiątek tysięcy więźniów politycznych, setkami zabitych i poszkodowanych. Tunezja zmaga się z wieloma problemami odziedziczonymi po starym systemie, utrzymującym się przy władzy przez ponad 20 lat poprzez stosowanie bezwzględnych represji. Nie ma to jednak porównania z ceną, jaką obecnie przychodzi płacić narodowi syryjskiemu, gdzie ofiary śmiertelne liczone są w tysiącach i gdzie niszczona jest infrastruktura, gdzie dochodzi do wydarzeń, które pozostawią ślady na przyszłe dziesięciolecia. Dyktatury są chorobą prowadzącą do ograniczania wolności, pobudzania nienawiści i przemocy. Europa zaznała stabilizacji dopiero po upadku dyktatur nazistowskiej i komunistycznej. ONZ powinna określić dyktaturę jako społeczną i polityczną plagę do zwalczania poprzez programy podobne do tych, które wyeliminowały takie choroby jak HeineMedina czy ospę. Na wzór Międzynarodowego Trybunału Karnego (ICC), który sądzi zbrodnie już po ich popełnieniu, potrzebne są mechanizmy zapobiegające 
powstawaniu dyktatur. One często przybierają pozory legalności (false legality) poprzez organizowanie fikcyjnych wyborów, podszywanie się pod zasady demokracji, odpowiednie poprawianie konstytucji. Tak miało się stać z wyborami w Tunezji planowanymi na 2014 r. Dyktatorzy wiedzą, że nie ma wewnętrznych czy międzynarodowych mechanizmów zapobiegawczych. Celowe byłoby zatem powołanie Międzynarodowego Sądu Konstytucyjnego, który demaskowałby niektóre akty konstytucyjne i rozstrzygałby spory co do legalności przeprowadzanych wyborów. Można powiedzieć, że Karta NZ i wiele międzynarodowych konwencji miały służyć jako przewodniki zasad zachowania państw, ale na ogół pozbawione są skutecznych mechanizmów weryfikacji realizacji tychże zasad. Systemy demokratyczne mogłyby być uznawane za takie przez wspomniany Sąd. Zainteresowane państwa mogłyby zwracać się o porady do takiej instytucji, która, z jednej strony, przeciwdziałałaby tyrańskim reżimom, a z drugiej, wzmacniałaby rolę oporu obywatelskiego.

Przewodniczący Generalnego Kongresu Narodowego (Parlamentu) Libii, Mohamed Yousef El-Magariaf, zaznaczył, że Libijczycy są zdecydowani na budowanie państwa pokojowego, $z$ dobrymi relacjami z sąsiadami i poszanowaniem międzynarodowych zobowiązań i praw człowieka. Z uznaniem wypowiedział się o ambasadorze Stanów Zjednoczonych Christopherze Stevensie, który wraz $\mathrm{z}$ towarzyszącymi mu osobami padł ofiarą zamachu terrorystycznego w Benghazi. Zapowiedział zwalczanie opóźnionych $w$ rozwoju terrorystów, którzy nie reprezentują ani Libii, ani islamu. Mówca wyraził poparcie dla strefy wolnej od broni jądrowej na BW i zaapelował o wywieranie presji, by przystąpiły do niej wszystkie państwa regionu. Poparł też prawa Palestyńczyków do niepodległego państwa oraz wezwał Radę Bezpieczeństwa do pilnego działania na rzecz przerwania przemocy w Syrii.

Prezydent Egiptu, Mohamed Morsi, powiedział, że jest pierwszym cywilnym szefem państwa wyłonionym w demokratycznych wyborach, jakie odbyły się w wyniku zwycięstwa rewolucji. Podejmowane po tym triumfie działania mają na celu ustanowienie nowoczesnego państwa ,na miarę aspiracji Egipcjan”, państwa bazowanego na rządach prawa, demokracji i poszanowaniu praw człowieka; dążącego do sprawiedliwości, prawdy, wolności, godności i społecznej sprawiedliwości. Egipska rewolucja nie była spowodowana ,podmuchem wiatru wiosny czy jesieni ani nagłego powstania, ale podobnie jak inne rewolucje w regionie, które ją poprzedziły, czy też po niej nastąpiły, wynikiem długotrwałych autentycznych ruchów narodowych ceniących sobie dumę i godność wszystkich obywateli”. Ta wizja „nowego Egiptu” będzie również przyświecała jego współpracy ze społecznością międzynarodową, prowadzoną w duchu równości, wzajemnego poszanowania i nieingerencji w wewnętrzne sprawy innych państw. „Nowy Egipt” jest zdecydowany odzyskać swą pozycję wśród państw i podejmować się skutecznej roli w sprawach globalnych. Zaangażowanie Egiptu w sprawy arabskie, islamskie i afrykańskie będzie odbiciem zasadniczej roli w obronie wzajemnie powiązanych losów, interesów i wartości. W tym kontekście mówca poparł dążenie Palestyń- 
czyków do niepodległego bytu, wezwał do natychmiastowego położenia kresu rozlewowi krwi i humanitarnemu kryzysowi w Syrii oraz do udzielenia wsparcia obydwu państwo sudańskim, a także nowym władzom Somalii.

Przez długie lata niektórzy błędnie próbowali budować stabilizację na opresji i tyranii. Także niestety niektórzy spośród nas akceptowali takie poczynania. Teraz, kiedy ludy regionu odzyskały wolność, nie będą już tolerowały pozbawiania należnych im praw czy to przez ich własnych przywódców, czy też przez siły zewnętrzne. Narody, zwłaszcza $z$ tego regionu, nie będą tolerowały pozostawania żadnego państwa poza Układem o nierozprzestrzenianiu nuklearnym (Nuclear Non-Proliferation Treaty - NPT), niestosowania systemu zabezpieczeń czy formułowania samowolnych gróźb. W tym względzie akceptowanie przez społeczność międzynarodową zasady uderzenia zapobiegawczego (pre-emptivesness) czy też próby jej zalegalizowania, byłoby w rzeczy samej sprawą poważną i stąd powinno być skutecznie zablokowane po to, by nie zachęcać do kierowania się prawem dżungli. $\mathrm{Z}$ tego też względu Egipt mobilizuje międzynarodowe wysiłki do zwołania (przed końcem br.) konferencji na rzecz ustanowienia BW strefą wolną od broni nuklearnej i wszelkiej innej broni masowej zagłady. Najlepiej byłoby pozbyć się w ogóle broni jądrowej.

Świat ma także obowiązek (responsibility) poparcia (realnie, a nie tylko werbalnie) wysiłków Afryki na rzecz rozwoju i wzrostu gospodarczego. Egipcjanie, sami będąc Afrykańczykami, są gotowi i chętni to czynić. Ponadto, młodzież stanowiąca większość społeczeństwa uważa, że rzeczywista legitymacja władzy pochodzi od woli narodu i nie może być narzucana przez apodyktyczne instytucje, które nie mają ani prawnej, ani moralnej do tego podstawy. Mówca przypomniał, że podczas niedawnego Szczytu Ruchu Państw Niezaangażowanych (NAM) w Teheranie zgłosił nową inicjatywę poświęconą sprawom młodzieży, zwracającą uwagę na edukację, szkolenie, zatrudnienie i zwiększenie udziału młodzieży w życiu politycznym. Do innych spraw wymagających poważnego potraktowania należą: reforma międzynarodowego systemu finansowego, rewitalizacja Zgromadzenia Ogólnego i reforma Rady Bezpieczeństwa.

5. Główni antagoniści w konflikcie bliskowschodnim, tak jak na poprzednich sesjach, przedstawili swe stanowiska w dłuższych wystąpieniach. Przewodniczący Zarządu Autonomii Palestyńskiej, Mahmoud Abbas, obok rutynowo powtarzanych zarzutów pod adresem władz Izraela, wyraził „,mimo złożoności sytuacji i frustracji nadzieję - może już ostatnią - na uratowanie rozwiązania konfliktu w oparciu o koncepcję »dwóch państw « i szczere dążenie do pokoju”. Podejście to musiałoby obejmować utworzenie niezależnego państwa palestyńskiego ze stolicą we Wschodniej Jerozolimie, na terytorium okupowanym od 1967 r., jak również rozwiązanie kwestii uchodźców, zgodnie z rezolucja 194 (III). Wezwał Radę Bezpieczeństwa (RB) do przyjęcia rezolucji dotyczącej fundamentalnych podstaw rozwiązania konfliktu palestyńsko-izraelskiego. Rezolucja ta byłaby „wiążącym strony punktem odniesienia (binding reference) do rozwiązania mówiącego o »dwóch państwach«. Niepodległość państwa palestyńskiego stanowi 
święte prawo (sacred right), które musi być zrealizowane". Przedstawiony przed rokiem wniosek do RB o członkostwo ONZ nie został uwzględniony, mimo popierania go przez znaczącą większość państw. Nadmienił, że Palestyna jest już członkiem UNESCO, gdzie prezentuje się w pełni profesjonalnie. W dążeniu do pełnego członkostwa NZ. Palestyna zamierza wystąpić do ZO na 67. sesji o przyznanie statusu państwa nieczłonka organizacji (non-member state of the UN).

Premier Izraela, Benjamin Netanyahu, oświadczył m.in.: ,[...] naszego konfliktu nie załatwi się przez zniesławiające wystąpienia w ONZ (with libellous speeches) lub przez jednostronne deklaracje o państwowości (or unilatral declarations of statehood)". Zamiast tego strony powinny usiąść do negocjacji w celu znalezienia rozwiązania, w którym ,zdemilitaryzowane państwo palestyńskie uznaje jedno i jedyne państwo żydowskie (in which a demilitarized Palestinian State recognized the one and only Jewish State)". Izrael chciałby widzieć trzy wielkie religie, których źródła znajdują się w tym regionie, współżyjące ze sobą w pokoju i wzajemnym poszanowaniu. Jednak nie są na to gotowe siły radykalnego islamu, chcące zapanować nad całym islamem, wygasić wolność i skończyć z nowoczesnym światem. Siły te mają różne odłamy, choć wywodzą się z tej samej gorzkiej gleby nietolerancji (bitter soil of intolerance). Wielkim zagrożeniem jest zdobycie dostępu do broni jądrowej przez Iran. Trzeba jednak, by społeczność międzynarodowa jak najszybciej postawiła temu dążeniu tamę (placed a clear red line).

6. Wicepremier i Minister SZ Syrii, Walid Al-Moualem, powiedział m.in., że zamiast skutecznie i w skoordynowany sposób prowadzonej współpracy w celu uporania się ze współczesnymi kryzysami, obserwuje się eskalacje hegemonii i dominacji. Zamiast rozwiązywania konfliktów i sporów środkami pokojowymi, niektóre znane kraje kontynuują , nową politykę kolonialną opartą na hipokryzji”. Pod pretekstem humanitarnej interwencji ma miejsce ingerowanie w sprawy wewnętrzne; jednocześnie nakładane są sankcje bez moralnej i prawnej podstawy. Bije się w bębny wojny pod pretekstem „odpowiedzialności za ochronę (responsibility to protect)". Szerzy bunty i niepokoje szkodzące strukturom społeczeństw narodowych. Najgorsze jest to, że stali członkowie RB narzucają wojny pod pretekstem „Zwalczania terroryzmu, obecnie w Syrii”. Istnieje tam, w wielu rejonach, „zorganizowany terroryzm”, przejawiający się w bombardowaniach, zabójstwach i masakrach, rabunku i sabotażu, ku przerażeniu mieszkańców. Nic więc dziwnego, że RB nie była w stanie tego potępić. Terroryzm jest wspomagany z zagranicy przy ,akompaniamencie prowokacji medialnych nastawionych na zapalanie ekstremizmu religijnego". Niektóre kraje albo udają, że tego nie widzą, albo wspierają te grupy terrorystyczne. Namawia się do nieskładania broni czy też do niekorzystania z amnestii (Katar, Arabia Saudyjska, Turcja, USA, Francja). Rząd pozytywnie odpowiada na każdą szczera inicjatywę w trosce o znalezienie pokojowego rozwiązania. Współpracuje z mediatorami: Kofi Annanem, a obecnie Lakhdarem Brahminim. Ale państwa (Turcja, Arabia Saudyjska, Katar, Libia $i$ in.) powinny zaprzestać wspierania wspomnianych grup, a rozpocząć zachęcanie do koncyliacji i odrzucenia przemocy. Kryzys w Syrii ma dwie strony: jedna 
to potrzeba reform politycznych i społecznych żądanych przez społeczeństwo, druga zaś to eksploatacja tych żądań do kompletnie innych celów. Rząd w ciągu 2012 r. dokonał poważnych zmian, przyjął nową konstytucję uznającą pluralizm, co znalazło wyraz w wyborach parlamentarnych. Poparła to „patriotyczna część opozycji”. Wzywanie z podium ONZ prezydenta do ustąpienia to rażąca ingerencja w sprawy wewnętrzne. Naród syryjski jest jedynym uprawnionym ciałem do kształtowania ustroju państwa. Rząd nadal wierzy w rozwiązanie polityczne jako drogi wyjścia z kryzysu. Mówca wezwał do zniesienia embarga w handlu z Syrią i z innymi państwami borykającymi się z podobnymi sankcjami (Wenezuela, Białoruś, Iran, Korea Płn.).

Minister SZ Turcji, Ahmet Davutoglu, podkreślił z kolei, że w wielu sprawach mówimy to samo, ale nie realizujemy tych deklaracji w podobnej jedności. Co roku powtarzamy, że rozwiążemy zamrożone konflikty: w Palestynie, Górskim Karabachu, na Cyprze - a one wciąż pozostają nierozwiązane. Do tych starych ciągle przybywają nowe, takie jak choćby ataki i zbiorowe karanie cywilnej ludności w Syrii. Jeśli nie możemy zmusić brutalnych reżimów do poddania się sprawiedliwości i rządom prawa, to jak możemy myśleć o utrzymaniu międzynarodowego pokoju i bezpieczeństwa. Ta niemożność tylko zachęca despotów do demolowania miast i osiedli, masakrowania ludności i wystawiania na śmieszność cywilizowanego świata i samej ONZ. Łaska okazana opresorowi oznacza wydanie wyroku na uciskanych przez niego poddanych. Niedawne ataki na proroka Mahometa i przeciw islamowi stanowily otwartą prowokację celem skłócenia narodów. Islamofobia stała się nową formą rasizmu, podobnie jak antysemityzm. Tego nie można tolerować pod przykrywką wolności słowa. Wolność nie oznacza anarchii, przeciwnie -wolność zobowiązuje do odpowiedzialności. Wyśmiewanie się z religii powinno być zaliczane do zbrodni nienawiści (hate crimes). Sprawa powinna być przedmiotem dyskusji i zaradzenia jej w ONZ. Idąca w dziesiątki tysięcy śmiertelnych ofiar tragedia syryjska dla wielu staje się po prostu statystyczna, tak jak wiele innych. Nic nie thumaczy impasu RB w tej sprawie. Odpowiedzialność za ochronę syryjskiej ludności staje się fundamentalnym obowiązkiem, nie mówiąc już o groźbie dla pokoju i bezpieczeństwa w całym regionie. W stagnacji pozostaje ,problem cypryjski”. Wznowione tam w 2008 r. rozmowy między Grekami i Turkami cypryjskimi zostały bezterminowo zawieszone przez cypryjskich Greków. Kontynuowanie problemu stwarza dodatkowe ryzyko dla stabilności regionu. Pogłębia je jednostronna akcja cypryjskich Greków poszukiwania wokół wyspy gazu. ONZ powinna ułatwiać rozwiązywania problemu, a nie tylko czuwać nad zachowaniem status quo. Powinno się realnie zająć koncepcją jakiejś formy federalizacji tej dwuwspólnotowej społeczności.

7. Premier Chorwacji, Zoran Milanovic, powiedział m.in., że jeśli każdy kraj będzie stawał się bardziej demokratyczny, bardziej rozwinięty, lepiej zarządzany, bardziej stabilny i bardziej odpowiedzialny, to łaczna siła, w tym ONZ, wzrośnie niepomiernie. A przecież rozwiązywanie międzynarodowych sporów leży w samym centrum zainteresowania Organizacji, która została stworzona po to, by za- 
pobiegać wojnom i utrzymywać pokój, przy użyciu cennych narzędzi dyplomacji prewencyjnej i mediacji. Chorwacja może poszczycić się np. rozwiązaniem sporu granicznego ze Słowenią. Nie wszyscy jednak respektują pokój i prawo międzynarodowe; ten rok nie jest pod tym względem zbyt udany, o czym świadczą niedawne wydarzenia w Libii i te trwające od kilkunastu miesięcy w Syrii. Szybka akcja w tym ostatnim kraju pozwoliłaby na przerwanie przemocy i na polityczną transformację przy wiodącej roli samej Syrii w zgodzie z aspiracjami jej społeczeństwa. To nie brak narzędzi do zapobiegania konfliktom, ale brak wystarczającej determinacji, by je użyć, jest przyczyną sytuacji, jakich jesteśmy świadkami. By prewencja była skuteczna, musi ona zaistnieć we wczesnej fazie konfliktu. Naturalnie jest miejsce na stałe doskonalenie narzędzi tejże prewencji czy to w Komisji Budowania Pokoju (PBC), czy w Radzie Praw Człowieka (HRC). Chorwacji powiodło się w pierwszej fazie stabilizacji pokonfliktowej (transition), co umożliwiło jej m.in. stanie się z początkiem 2013 r. członkiem UE. W podobnym duchu wypowiedział się też minister SZ Czarnogóry, Nebojsa Kaludjerovic.

8. Premier Włoch, Mario Monti, na czoło swego wystąpienia wysunął sprawę „największego w (50-letniej) historii kryzysu w UE”. Cytując słowa Jean Monneta, że „Europa była budowana poprzez kryzysy”, wyraził nadzieję, że i z obecnego kryzysu wyjdzie ona zwycięsko. Dzięki rozwiązywaniu kryzysów Europejczycy mogli się przekonać, jak ściśle zintegrowane są ich interesy i współzależne gospodarki. Sam świat też dostrzega, jak istotną sprawą dla wyjścia z globalnego kryzysu jest „sprawna (diable) Europa, i jak ważna dla ożywienia gospodarki globalnej jest strefa euro. Jasne jest jak 'więcej Europy' jest ważne dla interesów ogółu”. Kultura dialogu musi zapanować nad kulturą konfrontacji. Ekstremizm i nietolerancja muszą być odizolowane i odrzucone. Arabska wiosna doświadczyła trudności, chociaż niewątpliwie odnotowała też znaczące osiągnięcia. „Nic nie jest łatwe, ale też nic nie jest niemożliwe. Niczego też nie osiągnie się bez dobrej woli i działania w dobrej wierze". Jeśli świat chce położyć kres masakrom i masowemu łamaniu praw człowieka w Syrii, to musi być przerwany impas w RB blokujący międzynarodową akcję.

Prezydent Francji, François Hollande, w swym pierwszym wystąpieniu na tym forum podkreślił m.in., że uniwersalne wartości nie są własnością żadnego państwa czy jednostki. Chociaż należą do wszystkich, są często negowane $\mathrm{w}$ świecie ogarniętym fanatyzmem, stagnacją gospodarczą i zmianami klimatu. ONZ powinna stawić czoła tym wyzwaniom w sposób kompleksowy, uczciwy i sprawiedliwy. Mimo całej dobrej roboty ONZ nie była w stanie powstrzymać wojen i represji. By to stało się możliwe i by zostały osiągnięte wzniosłe jej cele, niezbędne są reformy, w tym dotyczące rozszerzenia RB. Francja popiera w tym względzie propozycje Niemiec, Japonii, Indii i Brazylii. Popiera też zwiększenie w Radzie reprezentacji Afryki, w tym w gronie stałych członków Rady. Członkostwo w Radzie to nie przywilej, ale obowiązek działania w sytuacjach wymagających wspólnego reagowania. Jedną z takich sytuacji jest kryzys w Syrii. Jak długo ONZ pozostanie sparaliżowana? Niezależnie od inercji społeczności 
międzynarodowej jedno jest pewne: obecny reżim syryjski nigdy już nie zazna miejsca we wspólnocie narodów. Mając to na uwadze, Francja podejmuje kroki w celu uznania rządu tymczasowego, wzywając jednocześnie ruch opozycyjny do tego, by odrzucił przemoc i przyspieszył działania na rzecz realizacji aspiracji społeczeństwa. Inną sprawą jest stanowczy opór przeciw proliferacji broni jądrowej, wskazując na przypadek Iranu. Należy też pomóc w przełamaniu impasu w negocjacjach między Palestyńczykami i Izraelem. „Status quo nie jest odpowiedzią, problemem jest trwający impas".

Nie do przyjęcia jest sytuacja okupowania przez terrorystów rejonów Sahelu. Stanowi to zagrożenie dla całego regionu. Działania ekstremistów muszą być potępione. „Mali musi odzyskać kontrolę nad swoim terytorium, a terroryści muszą zostać przepędzeni”. ONZ powinna położyć fundamenty pod budowę świata uczciwego i sprawiedliwego (fair \& equitable). Rewolucje arabskiej wiosny pokazały, że narody tęsknią za takim światem. Ruchy polityczne, które wyłoniły się po tych wydarzeniach, powinny nadal podążać ku demokracji i równości i odrzucić przemoc w każdych okolicznościach.

Premier Hiszpanii, Mariano Rajoy Brey, w swym wystąpieniu m.in. zaoferował państwom arabskim skorzystanie z trudnych, ale uwieńczonych sukcesem doświadczeń swego kraju z drogi, jaką przeszedł do demokracji. W procesie budowania otwartego, zintegrowanego (inclusive) społeczeństwa nie powinny dochodzić do głosu ruchy posługujące się przemocą. Hiszpania jest aktywna w poszukiwaniu rozwiązań kryzysów w Rogu Afryki, zwłaszcza w Somalii, w zwalczaniu piractwa na Oceanie Indyjskim i w niesieniu pomocy humanitarnej. W porozumieniu z WFP na Wyspach Kanaryjskich powstaną największe w świecie składy żywności, pozwalające na szybsze dotarcie tej pomocy do Afryki. Premier zaapelował o przerwanie przemocy w Syrii i uruchomienie politycznego procesu pozwalającego na pokojowe rozwiązanie kryzysu. Poparł rozwiązanie konfliktu palestyńsko-izraelskiego w oparciu o koncepcję $d w o ́ c h$ państw. Potępił akty przemocy na północy Mali. W kontekście nieproliferacji broni jądrowej wezwał Iran do podporządkowania się standardom IAEA oraz Koreę Płn. do rezygnacji z ambicji posiadania broni jądrowej i do poddania się odpowiedniej weryfikacji. Wezwał do reaktywowania Konferencji Rozbrojeniowej i odnowienia mandatu ZO ws. postępu w negocjowaniu traktatu dotyczącego handlu bronią. Hiszpania, ubiegająca się o członkostwo RB na lata 2015-2016, zamierza kontynuować działania na rzecz przygotowania kompleksowej konwencji o zwalczaniu międzynarodowego terroryzmu, odnotowując, że w Madrycie w lipcu 2012 r. odbyła się konferencja wysokiego szczebla poświęcona ofiarom terroryzmu. Wspólnie z Marokiem Hiszpania planuje wystąpienie z inicjatywą propagowania mediacji i budowania odpowiednich zdolności narodowych i lokalnych w basenie Morza Śródziemnego w oparciu o rezolucję ZO nr 65/283 z 22 czerwca 2011 r. pt. Strengthening the role of mediation in the peaceful settlement of disputes, conflict prevention and resolution, prace SG NZ i Grupy Przyjaciół ds. Mediacji (pod przewodnictwem Finlandii i Turcji). Zapowiedział aktywne 
poparcie dla sprawiedliwego, trwałego i wzajemnie akceptowalnego politycznego rozwiązania konfliktu ws. Sahary Zachodniej. Zwrócił się też do Wlk. Brytanii o wznowienie dwustronnego dialogu z Hiszpanią ws. dekolonizacji Gibraltaru zgodnie z parametrami ONZ.

9. Wydaje się, że jednym z interesujących wątków debaty generalnej 67 . Sesji Zgromadzenia Ogólnego NZ była wspomniana wyżej zapowiedź wspólnej hiszpańsko-marokańskiej inicjatywy odnoszącej się do propagowania mediacji i budowania narodowych i lokalnych zdolności ludzkich i organizacyjnych w tym zakresie. Jeszcze bowiem w trakcie trwania tej debaty, 27 września 2012 r., w siedzibie NZ miała miejsce prezentacja Wytycznych odnoszących się do organizowania skutecznych wysiłków mediacyjnych - Guidance for Effective Mediation - zawartych w raporcie Sekretarza Generalnego nt. roli mediacji w pokojowym rozwiązywaniu sporów (A/66/811 z 25 czerwca 2012 r.), przygotowanego zgodnie z rez. 65/283. Raport ten został przyjęty w rezolucji ZO nr 66/291 z 13 września 2012 r. z zaleceniem szerokiego rozpropagowania Wytycznych. Uznaje się w nim mediację za istotny środek (key means) realizacji celów i zasad Karty NZ. Odnosząc się do zaleceń raportu, Sekretarz Generalny NZ podkreślił, że niezbędne jest posiadanie „,wiedzy (know-how), umiejętności (dexterity) i partnerstwa (partnerships) niezbędnych do podejmowania mediacji w sposób profesjonalny i skuteczny" (dok. GA/11278 z 13 września 2012 r). Rezolucja 66/291 m.in. zachęca państwa członkowskie ONZ, jak również pozostałych aktorów (międzynarodowe i pozarządowe organizacje, społeczeństwo obywatelskie, instytucje subregionalne i lokalne) do współdziałania w zakresie tak mediacji, jak i innych środków wymienionych w rozdziale VI Karty, w zapobieganiu i rozwiązywaniu sporów i konfliktów zarówno wewnętrznych, jak i międzynarodowych. Wdzięczna rola w zakresie badań i popularyzacji wszystkich tych środków przypada także instytucjom akademickim.

Warszawa, 12.03.2014 r.

POST SCRIPTUM DO TEKSTU WIZJA BEZPIECZEŃSTWA W BASENIE MORZA ŚRÓDZIEMNEGO W ŚWIETLE WYSTĄPIEŃ PAŃSTW REGIONU W DEBACIE GENERALNEJ 67. SESJI ZGROMADZENIA OGÓLNEGO NZ (NOWY JORK, 25 WRZEŚNIA-1 PAŹDZIERNIKA 2012 R.)

Na przebieg debaty generalnej następnej, 68. Sesji ZO (wrzesień 2013 r.) niemały wpływ wywarły poprzedzające ją wydarzenia, takie jak m.in.: przyjęcie 4 kwietnia 2013 r. Układu regulującego nielegalny handel bronią lekką i strzelecką (The Arms Trade Treaty regulating the illicit trade in small arms and light weapons); zaawansowanie wysiłków na rzecz sformułowania agendy rozwojowej po $2015 \mathrm{r}$. (The Post-2015 Development Agenda); użycie w sierpniu 2014 r. broni chemicznej w Syrii; czy we wrześniu tegoż roku - atak terrorystyczny na centrum handlowe w Nairobi. Można zakładać, że na kolejną debatę 69. Sesji ZO we wrześniu 2014 r. istotny wpływ wywrą m.in. wydarzenia związane z sytuacją na Ukrainie, bezpo- 
średnio wiążące się już nie tylko z regionem BMŚ, ale i z Polską. Zwłaszcza że według niektórych opinii nie sposób zrozumieć historycznego tła tych wydarzeń, nie konfrontując ich z ,kilkusetletnią ekspansją polskiej szlachty na Wschodzie. Wyniszczyła ona Ukrainę ekonomicznie, społecznie i kulturowo w niemniejszym stopniu niż zachodnie imperia kolonialne wyniszczyły Afrykę i część Azji (Bogdan Huk, Ukraina - polskie jądro ciemności, , Le Monde Diplomatique”, luty 2014 r.).

Można się było spodziewać, że pod przewodnictwem przedstawiciela Ameryki Łacińskiej, wytrawnego blisko 60-letniego dyplomaty, ambasadora Johna W. Ashe (St. Przedst. Antigua \& Barbuda w ONZ i Międzynarodowej Organizacji Handlu, WTO), wiodącym tematem debaty 68 . Sesji będzie problematyka rozwojowa, a mianowicie kwestia przygotowania celów trwałego rozwoju (SDGs) na okres po 2015 r. - The Post-2015 development agenda: Setting the Stage.

Sekretarz Generalny NZ Ban Ki-moon podkreślił, że ,żyjemy w erze zadziwiających możliwości wykorzenienia ubóstwa w przeciągu jednego pokolenia. Jednak presja na planetę $\mathrm{w}$ postaci m.in. bezrobocia młodzieży, zmian klimatu, nierozwiązanych konfliktów, narasta, a wydarzenia w terenie wymykają się spod kontroli i systemów obliczonych na inne czasy. ${ }^{3}$ Imponujący postęp w realizacji niektórych Milenijnych Celów Rozwoju (MDGs), ale i nienadążanie w innych, jak i pogłębianie się nierówności społecznej powodują, że cele trwałego rozwoju na okres po 2015 r. powinny nie tylko inspirować do działania, ale i iść dalej w skutecznym ich wdrażaniu poprzez lepsze zarządzanie. Powinny składać się na jeden zestaw takich celów, nie odkładać spraw środowiska i sprawiedliwości społecznej na później, do czasu osiągnięcia wzrostu gospodarczego. Kryzys w Syrii jest największym wyzwaniem dla pokoju i bezpieczeństwa świata. Także region został niebezpiecznie zdestabilizowany, a stracone pokolenie młodych ludzi wypełniło obozy dla uchodźców, czując się opuszczonymi przez społeczność międzynarodową. Skoro losy świata są coraz bardziej ze sobą splecione w globalnej transformacji, nowe sposoby zarządzania, partnerstwa i rozwiązywania problemów muszą być znalezione. Umocnijmy też Narody Zjednoczone, by były nie tylko pierwszym adresatem tychże problemów, ale też nie ostatnią deską ratunku".

W debacie generalnej wzięły udział wszystkie państwa członkowskie regionu (20) oraz Palestyna jako nieczłonek NZ. Wielkim nieobecnym w stosunku do roku 2012 był odsunięty od władzy po niespełna roku prezydent Egiptu Mohamed Morsi. Występujący w imieniu Egiptu minister SZ Nabil Fahmy powiedział m.in., że „ostatnie wydarzenia w jego kraju wykazały, że obywatele mogą zarówno udzielić jak i cofnąć zaufanie do osoby sprawującej najwyższy urząd, jeśli jest ono nadużywane". Odnosząc się do innych spraw, mówca zapowiedział inicjatywę zapewniającą prawo do „równego bezpieczeństwa w regionie poprzez ogłoszenie go wolnym od broni jądrowej, chemicznej i biologicznej”, apelując o poparcie dla tej idei zarówno do wszystkich państw Bliskiego Wschodu, jak i do stałych członków Rady Bezpieczeństwa NZ. Zapowiedział też rychłe powołanie do ży-

$3<$ http://gadebate.un.org/68/secretary-general-united-nations $>$. 
cia Egipskiej Agencji Partnerstwa na rzecz Rozwoju, której większość środków byłaby kierowana do krajów afrykańskich.

Z innych wypowiedzi na uwagę zasługuje wystąpienie Szwajcarii, wyrażające zaniepokojenie powrotem do polityki równowagi sił (power politics), a także tym, że zbyt dużo w ONZ mówi się o tym jak sprawy powinny wyglądać, a za mało o tym, jak one de facto wyglądają.

Podsumowując debatę, ambasador John Ashe podkreślił, że była ona pożyteczna, zaakcentowała bowiem najważniejsze sprawy (the issues at the forefront of our lives). Jest to praktycznie ,jedyny mechanizm”, gdzie głos 193 członków organizacji może być wysłuchany. „Często zarzuca się nam, że jesteśmy organizacją do wygłaszania przemówień, a nie podejmowania działań. Być może tak jest, ale wg mnie nasze doroczne debaty generalne w tej porze roku służą ważnemu celowi; pozwalają zaznaczyć gdzie się znajdujemy jako społeczność międzynarodowa, ale także zawierają wskazówki co do tego dokąd powinniśmy zmierzać; stanowią pożyteczny punkt dla partnerskiego (rówieśniczego) oglądu sytuacji i ogólnej sprawozdawczości co do podjętych działań (a useful point of peer review and general accountability)".

Teraz od poszczególnych państw, ale i od społeczeństwa obywatelskiego zależy znalezienie wspólnego mianownika (common ground) wśród priorytetów, jako ew. podstawy do pójścia do przodu ze zdecydowaną akcją. W realnym świecie taki zdrowy kompromis jest najlepszym efektem wspólnego wysiłku. ${ }^{4}$

Wydaje się, że zarówno w analizach ocen dotyczących konkretnych problemów, jak i w poszukaniu wspólnej bazy do działania, tak w trybie dwustronnym, jak i wielostronnym, rządowym i pozarządowym, wdzięczne pole do popisu mają m.in. uczelnie wyższe. Debaty generalne dorocznych sesji ZO stanowią więc cenne i systematyczne źródło informacji, ale także inspiracji do ew. wychodzenia $\mathrm{z}$ inicjatywami $\mathrm{i}$ ich testowania, m.in. także na uniwersalnym forum, jakim są agendy systemu NZ.

VISION OF MEDITERRANEAN SECURITY IN THE GENERAL DEBATE OF THE 67TH UN GENERAL ASSEMBLY SESSION (NEW YORK, 25 SEPTEMBER - 1 OCTOBER 2012)

\begin{abstract}
General debates of the annual sessions of the United Nations General Assembly (UNGA) get public attention. For the Mediterranean region the debate in the 67th GA session was significant due to the appearance of new political leaders emerging after the 2011 Arab Spring. Revolutionary changes in the MENA region resonated in the key speeches of the general debate that in turn anticipated events which we are facing today. As such, general debates of UNGA sessions provide a valuable source of information as well as an important agenda-setting mechanism.
\end{abstract}

Key words: the $67^{\text {th }}$ session of the UN General Assembly, the Mediterranean region, Arab Spring

$4<$ http://gadebate.un.org/68/presidnet-nga-closing $>$. 